\title{
ŁASKA BOŻA I JEJ NIEODZOWNA POMOC W UTRZYMANIU NADZIEI W CODZIENNYM ŻYCIU CZLOWIEKA NA PRZYKLADZIE PISM PAULINA Z NOLI**
}

Nawrócenie Paulina z Noli († 431) było wydarzeniem o wielkim znaczeniu społecznym i eklezjalnym, zaskoczeniem prawie dla wszystkich, a zwłaszcza dla niego samego ${ }^{1}$. Ambroży dzieli się z Sulpicjuszem Sewerem wieścią o tak głębokim nawróceniu i przewiduje, jaka będzie reakcja społeczna ${ }^{2}$. Także znaczna czesść biskupów z trudem akceptowała radykalizm jego nawrócenia $^{3}$. Najbardziej jednak Paulina zaskoczyła postawa papieża Syrycjusza, który w ogóle go nie przyjął i nawet nie chciał go widzieć. Paulin pisze, że w ten sposób najbardziej obrażona została przez papieża łaska powołania go przez samego Jezusa Chrystusa. Oskarża nawet papieża o kierowanie się pychą ${ }^{4}$. Problem był tym bardziej poważny, że w czasie pobytu w Rzymie Paulin ciężko zachorował i jedynie dzięki pomocy tamtejszych mnichów i wiernych przeżył, a po powrocie do zdrowia udał się w dalszą drogę do Cimitile. Papież nie wierzył w szczerość nawrócenia Paulina i podobnie jak znaczna część episkopatu podejrzewał go o pryscylianizm.

\footnotetext{
* Ks. prof. dr hab. Jerzy Pałucki - kierownik Katedry Patrologii Greckiej i Łacińskiej w Instytucie Historii Kościoła i Patrologii na Wydziale Teologii Katolickiego Uniwersytetu Lubelskiego Jana Pawła II; profesor wizytujący na Wydziale Teologii Uniwersytetu im Księcia Witolda w Kownie (Litwa); e-mail: palucki@poczta.fm.

** Praca powstała w ramach realizacji projektu badawczego nr 2014/15/B/HS1/03851 finansowanego ze środków Narodowego Centrum Nauki.

${ }^{1}$ Por. J. Pałucki, Paulin z Noli. Zapomniany przez wieki, wzorem teologa na dzisiejsze czasy, w: Sprawiedliwość, pokój i radość w postugiwaniu biskupim. Księga pamiątkowa ku czci Jego Ekscelencji Księdza Biskupa dr. Wiestawa Alojzego Meringa z okazji 65. rocznicy urodzin, red. A. Niemira - K. Rulka - J. Szymański, Włocławek 2010, 419-428.

${ }^{2}$ Por. Ambrosius, Epistula 27, 3, ed. G. Banterle, SAEMO 19, Milano - Roma 1988, 252, thum. P. Nowak: Św. Ambroży, Listy, t. 1, BOK 9, Kraków 1997, 198.

${ }^{3}$ Por. D.E. Trout, Paulinus of Nola: life, letters and poems, Berkeley 1999; G. Santaniello, Vita di Paolino da Bordeaux vescovo di Nola, Nola - Marigliano 2015.

${ }^{4}$ Por. Paulinus Nolanus, Epistula 5, 14, 2-3, ed. G. Santaniello: Paolino di Nola, Le Lettere, t. 1, Napoli - Roma 1992, 242: „quantum nobis gratiae dominicae detrimentum faciat Urbis papae superba discretio, qui paucis ipsis diebus interfuere viderunt".
} 
Już na samym początku należy zaznaczyć, że łaska (gratia) w ujęciu Paulina z Noli nie oznacza jedynie łaski uświęcającej udzielanej w sakramentach, choć jest ona najistotniejsza, ale jest także, a może nawet przede wszystkim, darem codziennie udzielanym przez Boga, na różne sposoby, pomagającym człowiekowi we wzrastaniu duchowym, ale także intelektualnym ${ }^{5}$.

Zarówno Pieśni, jak i Listy, są pisane trudnym językiem, mimo deklaracji Paulina, że porzuca jako bezużyteczne poezję i całą kulturę antyczna, zaznaczając, że jego jedyną sztuką, którą pragnie kultywować, i tym, co go interesuje, jest jedynie wiara ${ }^{6}$. Jednak po pewnym czasie, chyba nieświadomie, nawet jego listy pisane niby prozą stawały się utworami poetyckimi (biała poezja). Utrudnia to ich zrozumienie, zwłaszcza w kwestiach dogmatycznych, w których - jak sam zaznacza - nie jest jeszcze pewny i ciagle się uczy. W wielu wypadkach można odnieść wrażenie, że ociera się prawie o heretyckie pojęcia, zwłaszcza dotyczące Trójcy Świętej ${ }^{7}$. Dotyczy to choćby sformułowania, że Jezus Chrystus rozdziela łaski otrzymane od Boga. Jednak później wielokrotnie powtarza, w nawiązaniu do dokumentów synodalnych oraz być może korygowany przez Augustyna i Hieronima, że Ojciec i Syn, i Duch Święty mają jedną naturę, jednak różnią się $\mathrm{w}$ działaniu na zewnątrz ${ }^{8}$.

W liście do przyjaciela Amanda poucza go jak wielki jest dar łaski uświęcającej i odpuszczenia grzechów. Paulin przyznaje, że człowiek, nawet najbardziej wierzący, czuje się zdruzgotany swą słabością i popełnionymi grzechami. Często postanawia poprawę, ale lenistwo sprawia, że brnie dalej w grzechy, dlatego Paulin wzywa, aby nieustannie powstawać z martwych, zaczynać od nowa życie i powracać do Chrystusa ${ }^{9}$. Poucza jak bardzo ważna jest pomoc wspólnoty, zwłaszcza najbliższych przyjaciół, którzy stają się „pontonem” pomagającym dopłynąc do okrętu wiodącego do portu ${ }^{10}$. Potwierdza to w Pieśni 19., pouczając, że Chrystus raz na zawsze wiąże węzłami demony z ich okrucieństwem, a Jego łaska pozostaje, zwłaszcza poprzez wstawiennictwo świętych, w każdym ochrzczonym, uwalniając go od grzechów. Także ich mocą chrześcijanin ciągle

${ }^{5}$ Por. S. Mratschek, Der Briefwechsel des Paulinus von Nola: Kommunikation und soziale Kontakte zwischen christlichen Intellektuellen, Göttingen 2002.

${ }^{6}$ Por. Mia sola arte è la fede: Paolino di Nola teologo sapienziale, ed. L. Longobardo - D. Sorrentino, Napoli 2000.

${ }^{7} \mathrm{Z}$ jednoznacznym zrozumieniem pewnych wypowiedzi Paulina mieli już trudności znawcy literatury i teologii w czasach nowożytnych, por. S. De Rinaldis, Paolineide. Testo latino, traduzione italiana, note e indici, a cura di A. Ruggiero, Strenae Nolanae. Collana di studi diretta da A.V. Nazzaro 9, Marigliano 2002.

${ }^{8}$ Por. R. Eiswirth, Hieronimus' Stellung zur Literatur und Kunst, Wiesbaden1955; H. Pietras, Początki teologii Kościoła, Kraków 2000, 144-267.

${ }^{9}$ Por. Paulinus Nolanus, Epistula 9, 2, 18, ed. Santaniello, t. 1, s. 298: ,erige te a mortuis, ut adtingas Christum"; M. Skeb, Christo vivere: Studien zum literarischen Christusbild des Paulinus von Nola, Bonn 1997.

${ }^{10}$ Por. Paulinus Nolanus, Epistula 9, 2, 19-21, ed. Santaniello, t. 1. s. 298: „Quem fidem dominum interventu fidei vestrae per gratiae sacramentum inposuisti in naviculum cordis nostri". 
odpędza demony, które chcą z człowieka czynić swego niewolnika ${ }^{11}$. Paulin przywołuje nawrócenie Szawła, a następnie uratowanie go na morzu. Ponieważ Paweł był zawsze zjednoczony z Chrystusem, uratował wielu, którzy byli blisko niego. Działania apostolskie Pawła oraz napisane przez niego listy są dla każdego chrześcijanina nośnikiem łaski, którą Apostoł Narodów otrzymał od Chrystusa (por. Dz 27, 22-26) ${ }^{12}$. Brak łaski sprawia, że człowiek staje się niewolnikiem szatana i ceni wyżej to, co ziemskie, niż to co wieczne ${ }^{13}$.

Paulin rozróżnia łaskę Bożą, łaskę Chrystusa, łaskę Ducha Świętego i łaski spływające za pośrednictwem świętych. Najczęściej jednak przywołuje Chrystusa jako dawcę łaski Bożej, ale też często pisze o łasce Chrystusa (ipse est potentis larga Christi gratia $)^{14}$. Nigdzie nie kwestionuje istoty i działania Trójcy Świętej, jednak jako poeta jest w tekstach, zwłaszcza poetyckich, zbyt mało precyzyjny, za co został wielokrotnie skrytykowany przez Hieronima.

Przypominając biblijny przekaz o Józefie Egipskim Paulin przywołuje imię Chrystusa i zaznacza, że jako zarządca dóbr faraona miał prawo noszenia uroczystego stroju i złotego łańcucha, które przysługują Chrystusowi. Dla Józefa był to strój niewinności i znak łaski Bożej ${ }^{15}$. Opisując chrześcijańskie zaślubiny, przywołuje biblijny tekst mówiący o stworzeniu Adama i Ewy, i zaznacza, że młoda panna chrześcijańska nie stroi się w złoto i klejnoty, ale jej ozdobą jest łaska Boga ${ }^{16}$. Podobnie opisując niedowiarstwo Apostoła Tomasza przypomina, że uwierzył on dopiero, gdy zobaczył zmartwychwstałego Chrystusa. Podobnie na końcu świata Bóg objawi cała prawdę i niedowierzający zobaczą uwielbione ciało Ukrzyżowanego ${ }^{17}$.

Paulin wyraźnie deklaruje ortodoksyjną naukę o Trójcy Świętej, akcentując jedność natury poszczególnych Osób, jednak wskazuje na pewne rozróżnienie (zresztą ortodoksyjnie) że Syn jest zrodzony z Ojca, a Duch Święty pochodzi od Ojca ${ }^{18}$. Przywołując zesłanie Ducha Świętego w Wieczerniku zaznacza, że posłany z nieba dał On pod postacią ognistych języków moc wszystkim tam obecnym i ten sam Jedyny Bóg podąża w świat poprzez poszczególne osoby napełnione mocą Ducha ${ }^{19}$.

${ }^{11}$ Por. tenże, Carmen 19, 230-240, ed. A. Ruggiero: Paulino di Nola, I Carmi, t. 1, Napoli - Roma 1996, 368. Zob. A. Nola, Il diavolo. Le forme, la storia, le vicende di Satana e la sua universale e maleficia prezenza presso tutti i popoli, dall' antichità ai nostri giorni, Roma 1987.

${ }^{12}$ Por. Paulinus Nolanus, Carmen 24, 285-298, ed. Ruggiero, t. 2, s. 138.

${ }^{13}$ Por. tamże 24, 567-584, ed. Ruggiero, t. 2, s. 156.

${ }^{14}$ Por. tamże 33, 8, ed. Ruggiero, t. 2, s. 402; G. Santaniello, San Paolino di Nola una vita per Cristo, Napoli 1994.

${ }^{15}$ Por. Paulinus Nolanus, Carmen 24, 780-786, ed. Ruggiero, t. 2, s. 168.

${ }^{16}$ Por. tamże 25, 43-46, ed. Ruggiero, t. 2, s. 184: „Horreat inclusas auro vel murice vestes; aurea vestis huic gratia pura Dei est".

${ }^{17}$ Por. tamże 27, 415-423, ed. Ruggiero, t. 2, s. 270.

${ }^{18}$ Por. tamże 19, 137, ed. Ruggiero, t. 2, s. 360: „Sola Dei natura Deus, quod filius et quod spititus et pater est; sed filius ex patre natus, spiritus ex patre procedens".

${ }^{19}$ Por. tamże 27, 60-65, ed. Ruggiero, t. 2, s. 242. 
W codziennym życiu, gdy chrześcijanin dręczony jest ogniem pokus, to właśnie Duch Święty jest tym, który gasi te płomienie namiętności i ,nawadnia" kości śmiertelnych ciał ${ }^{20}$. Zaznacza też, że to Duch Święty napełnia żywą łaską groby świętych. W ten sposób Paulin wskazuje na działanie łaski pochodzącej od Boga (Ojca) za pomocą Ducha Świętego poprzez relikwie ${ }^{21}$. Wyraźnie zaznacza, że działanie łaski Bożej za pośrednictwem świętych nie dotyczy tylko ich grobów, ale każdego miejsca, w którym są nawet najmniejsze ich cząstki (relikwie). Paulin jest o tym przekonany, gdyż - jak pisze - Bóg daje dowody swego działania poprzez relikwie, gdziekolwiek się znajdują ${ }^{22}$.

W Liście do Amanda ${ }^{23}$ dzieli się swym doświadczeniem zaskoczony, że Bóg wybrał sobie właśnie jego - grzesznika i kruchego człowieka. Stwierdza, że to łaska Chrystusowa za wstawiennictwem św. Feliksa sprawia, iż wzrasta jego wiara, i pomaga w nabywaniu kolejnych cnót, potrzebnych do zwalczania przeciwności. Zaznacza wielokrotnie, że swoje nawrócenie i wszystko, co teraz czyni, zawdzięcza wstawiennictwu św. Feliksa, którego pośrednictwo w rozdawnictwie łask Chrystusowych nie skończyło się wraz ze śmiercią męczeńską ${ }^{24}$. Dotyczy to wszystkich wiernych, którzy przechodząc do wieczności ciągle wspierają żyjących na ziemi, a ich groby (relikwie) są „,̇ywe” i przekazują łaski ${ }^{25}$.

Rozważając tajemnicę swego powołania do życia ascetycznego, a następnie na prezbitera i biskupa, wyznaje, że rozpoznał, iż Chrystus, który jest wyposażony we wszelkie dary, umacnia wiarę, ubogaca wiedza, aby wybrańcy byli napelnieni pełnią łaski (ut et in hac gratia abundetis; por. 2 Kor 8,7$)^{26}$. Dlatego dodaje otuchy przyjacielowi, aby się nie obawiał przekazanej mu łaski służenia jako prezbiter przy ołtarzu, choć należy się z pokorą przyznawać, że jesteśmy jeszcze dziećmi pod względem intelektualnym, ubogimi w słownictwo, potrzebującymi ciagłego kształcenia się, a wszystkiego dopełnia darowana łaska. Wyznaje, że święcenia prezbiteratu przyjął prawie przymuszony przez wiernych z Bordeaux i choć prosił Pana, aby oddalił od niego ten kielich, ostatecznie jednak uległ woli Boga. Nawrócenie Paulina było, jak to już wyżej wskazano, wydarzeniem o wielkim znaczeniu społecznym i kościelnym oraz zaskoczeniem prawie dla wszystkich. Nie dziwi więc, że Ambroży przewidywał, iż reakcja społeczna, zwłaszcza wśród rodów arystokratycznych, będzie burzliwa ${ }^{27}$.

${ }^{20}$ Por. tamże 24, 635-638, ed. Ruggiero, t. 2, s. 160: „Maxilla telum proelianti quae dedit dat aestuanti poculum ieiuna suci carnis ossa mortuae sancto rigante spiritu"; S. Prete, Motivi ascetici e letterari in Paolino di Nola, Napoli - Roma 1987.

${ }^{21}$ Por. Paulinus Nolanus, Carmen 21, 624-633, ed. Ruggiero, t. 2, s. 56.

${ }^{22}$ Por. tamże 27, 440-447, ed. Ruggiero, t. 2, s. 272.

${ }^{23}$ Por. tenże, Epistula 2, 1 - 3, 8, ed. Santaniello, t. 1, s. 180-182.

${ }^{24}$ Por. tenże, Carmen 26, 240-248, ed. Ruggiero, t. 1, s. 282.

${ }^{25}$ Por. tamże 21, 625-635, ed. Ruggiero, t. 2, s. 56.

${ }^{26}$ Por. tenże, Epistula 2, 1, ed. Santaniello, t. 1, s. 182.

${ }^{27}$ Por. tamże 27, 3, SAEMO 19, 253-254, BOK 9, 98; Instrukcja o studium Ojców Kościoła, w: W szkole Ojców Kościoła w nauczaniu Jana Pawła II, red. M. Raczkiewicz, Kraków 2008, 35-40. 
Paulin podkreśla, że należy ciągle, z pomocą łaski, uczyć się w jaki sposób obchodzić się ze świętymi tajemnicami. Przyznaje jednak, że Bóg nikogo do niczego nie przymusza, jedynie zaprasza i udziela pomocy w rozpoznaniu właściwej drogi. Pisząc do Sewera, przypomina, że jest to dar ofiarowany, a nie narzucony, jak Prawo.

Łaskę Boga ofiarowaną przez Niego w nauczaniu Starego Testamentu Paulin porównuje do cierpkiego napoju i surowego obowiązku. Powołanie do kapłaństwa czy życia pustelniczego daje szanse wolnego wyboru i przez to, jeśli nawet człowiek czuje się początkowo zniewolony, to otrzymuje dar zrozumienia wielkości łaski i przyjmuje ją jako mleko miłosierdziaa ${ }^{28}$.

W kolejnym liście, skierowanym tym razem do Augustyna Paulin wyznaje z bólem, że dotychczas pokładał zbyt wielkie zaufanie w ludzkiej wiedzy i zachwycał się mądrością tego świata. Jego rozmiłowanie w literaturze i fałszywej wiedzy czyniły go głuchym w obliczu Boga. Dopiero z pomocą Pana, który nie zważał na jego grzeszne dotychczas życie, zdołał zerwać kajdany światowego brudu. Bóg oświecił jego umysł i uniżył go w jego pustej pysze, ale za to wyniósł na wyżyny duchowe dzięki świętemu upokorzeniu ${ }^{29}$. Zdaniem Paulina, niemałą zasługę w tym nawróceniu i pokornym przyjęciu posługi prezbitera miały modlitwy przyjaciół zanoszone do Tego, który w swym miłosierdziu go przygarnął i wybrał. Zaleca też Augustynowi, aby nie zwracał uwagi na jego dojrzały wiek, co nie ma żadnego znaczenia, lecz traktował go jako dziecię, które dopiero zaczyna uczyć się chodzić, bo dopiero wówczas narodził się na nowo duchowo, dzięki łasce otrzymanej od Boga. Jak zauważa G. Guttilla, Nolańczyk wielokrotnie swoje narodzenie duchowe wiąże nie z chrztem, który otrzymał w 389 r., ale dopiero z tzw. drugim nawróceniem ascetycznym, które miało miejsce w latach $392-393^{30}$. Paulin uważa, że łaska wiary otrzymana od Boga może i powinna być umacniana modlitwą przyjaciół i ich pouczeniami (fratri fratrum adiuvanti) ${ }^{31}$. Tylko bowiem w ten sposób nowo nawrócony może uciec od pokus tego świata i razem z nimi podążać do portu zbawienia ${ }^{32}$. Duchowe wsparcie oraz pouczenia mocniejszych w wierze Paulin określa jako pewnego rodzaju ,szalupę”, przy pomocy której można dotrzeć do celu, ratując się z brudów tego świata. Są one jak potop zanurzający słabych w wierze

${ }^{28}$ Por. Paulinus Nolanus, Epistula 23, 27, 15-19, ed. Santaniello, t. 1, s. 672: „In quo opinor significari, quod dulcior sit libertas gratiae in lacte misericordiae quam in vino iustitiae legis austeritas. Littera enim, inquit, occidit, vides censurae merum; spiritus autem vivificat, vides uberum munus et lactis effectum”; P.G. Walsh, Textual Notes on The Epistular of Paulinus Nolanus, „Orpheus” 13 (1966) 153-158; C. Conybeare, Paulinus noster: self and symbols in the letters of Paulinus of Nola, Oxford 2000.

${ }^{29}$ Por. Paulinus Nolanus, Epistula 4, 2, 20-29, ed. Santaniello, t. 1, s. 208.

${ }^{30}$ Por. G. Guttilla, Eta fisica ed eta spirituale nei ,C Carmi” di Paolino di Nola, „Civiltà Classica e Cristiana" 11 (1990) 171-181.

${ }^{31}$ Por. Paulinus Nolanus, Epistula 6, 3, 25, ed. Santaniello, t. 1, s. 266.

${ }^{32}$ Por. tamże 4, 3, 24-26, ed. Santaniello, t. 1, s. 210: „tu, qui iam solido litore constitisti, tuto excipe sinu, ut in portu salutis, si dignum putas, pariter navigemus". 
w odmętach tego świata. Dlatego też Paulin, podejmując studia nad lektura Pisma Świętego, często konsultował z przyjaciółmi, szczególnie z Augustynem i Hieronimem, w jaki sposób interpretować określone jego fragmenty.

Zdaniem Paulina, przyjaźń i pomoc przyjacielska jest darem danym od Boga i przejawem Jego łaski ${ }^{33}$. Paulin bardzo sobie cenił przyjaźń z innymi ludźmi i uważał, że jest ona darem Najwyższego. Zostanie ona doceniona przez Boga, gdy brat pomaga bratu. Paulin wyznaje swemu przyjacielowi Sewerowi, że to dzięki jego dobrym dziełom, nawet w chorobie pomoc przyjacielska jest niezwykle ważna, gdyż ma podwójne znaczenie - wzmacnia ciało, ale - co ważniejsze - umacnia duszę. Różnego rodzaju pomoc w trudnościach, jeśli jest niesiona $\mathrm{z}$ wiarą, choć sam pomagający boryka się $\mathrm{z}$ trudnościami, staje się nośnikiem łask i jakby olejem radości umacniającym duszę, choć pochodzącym $w$ pewnym sensie z zewnątrz ${ }^{34}$. Nawet proste pożywienie, jeśli jest przygotowane $z$ wiarą i modlitwą, nabiera szczególnego smaku i dodaje sił, gdy jest doprawione oliwą łaski, której nie sposób przecenić, i nie zastapią go najwytworniejsze dania przygotowane przez wytrawnych kucharzy ${ }^{35}$.

Paulin prawdopodobnie nie znał osobiście Augustyna, jednak dzięki korespondencji oraz wspólnemu dążeniu do tego samego „portu zbawienia” osiagnęli wręcz doskonałą - jak na ludzkie możliwości - duchową jedność. Przekonuje Hippończyka w jednym z listów, że to właśnie łaska Boga (gratia Dei), jak wskazano wyżej, przekazywana przez Jezusa Chrystusa sprawia, że znają się nie tylko duchowo, ale wręcz jakby widzieli swoje cielesne oblicza $^{36}$. Oczywiście, dodaje, że byłoby prawdziwym szczęściem spotkać się także osobiście, co by dopomogło we wzajemnym umacnianiu się w wierze, a także ubogacało ich umysły. Jednak i tak jest szczęśliwy, że Pan obdarzył go łaską takiej duchowej łączności. Uważa, że Augustyn otrzymał nadzwyczajną łaskę poznawania Bożych tajemnic i dzielenia się swą wiedzą w tym zakresie z innymi, zwłaszcza przez pisanie kolejnych dzieł literackich. Dlatego życzy Augustynowi, aby ten nadzwyczajny dar od Boga zawsze mu towarzyszył i służył innym. Paulin potwierdza, że Hippończyk prawie do każdego listu dołączał jakieś nowe dzieło lub chociażby fragment aktualnie tworzonego, którego jeszcze nie zakończył ${ }^{37}$. To umacniało Paulina i cała wspólnotę mnichów i mniszek z pustelni w Cimitile w pewności, że są na dobrej drodze, i dodawało otuchy, że pomimo codziennych trudności, wręcz walki

\footnotetext{
${ }^{33}$ Por. J. Pałucki, Eklezjotwórcza funkcja przyjaźni w nauczaniu Paulina z Noli, SWł 14 (2012) 88-104.

${ }^{34}$ Paulinus Nolanus, Epistula 23, 5, 28-30, ed. Santaniello, t. 1, s. 622: „mentis quoque vigorem recreatis ossibus erigebat cooperante procul dubio manibus fide, ut dum infirmam carnem manus diligentis duceret, conpatientem animam gratia credentis elueret fieretque mihi intus oleum laetitiae quod foris erat oleum sanitatis".

${ }^{35}$ Por. tamże 23, 6, 10-10, ed. Santaniello, t. 1, s. 622.

${ }^{36}$ Por. tamże 6, 3, 8-11, ed. Santaniello, t. 1, s. 266: „Quare utinam hoc quoque nobis munus adnueret gratia Dei per dominum nostrum Jesum Christum, ut etiam in carne faciem tuam videremus".

${ }^{37}$ Por. tamże 6, 24, ed. Santaniello, t. 1, s. 266 (zob. też tamże, s. 267, nota 7).
} 
o przetrwanie i wyżywienie zgłodniałych pielgrzymów i okolicznych biedaków, nie ustaną w nadziei.

W Liście do Delfina, umocniony lekturą pism Augustyna i widokiem codziennych cudów przy relikwiach męczennika Feliksa, w tym także swego rodzaju ,rozmnażania chleba” w mensie dla ubogich przybywających do Cimitile, przypomina, że jest to owoc łaski. Zwraca uwagę, że Syn Boży został ukrzyżowany w swej (ludzkiej) słabości (ex infirmitate), a dokonuje nieustannie wielkich dzieł dzięki łasce (ex virtute Dei). Dlatego i jego naśladowcy nie powinni obawiać się w swej ludzkiej bezradności iść śladami Syna, gdyż i oni będą mocni Bogiem, zdolni do dokonywania wielkich rzeczy, mimo ludzkiej kruchości ${ }^{38}$.

W liście kondolencyjnym do swego przyjaciela Pammachiusza pisze, aby po stracie małżonki nie pozostawił sobie ogromnego majątku, lecz rozdał go ubogim. Pammachiusz na posiedzenia senatu chodził ubrany we włosiennicę narażając się na drwiny i stając się pośmiewiskiem. Zgodnie z poleceniem Paulina organizował mensy dla ubogich, a punktem najbardziej spektakularnym było urządzenie obiadu dla wszystkich ubogich Rzymu, zgromadzonych na wzgórzu watykańskim. To wydarzenie także porównuje Paulin do cudownego rozmnożenia przez Jezusa chleba na pustyni. Wreszcie pisze, że jest to potwierdzenie wiary i podążania drogą Jezusa ${ }^{39}$. Zaznacza przy tym, ze mimo ogromnej fortuny Pammachiusza organizowanie takich uczt dla ubogich byłoby niemożliwe bez pomocy Chrystusa. Paulin uważa, że w takich przypadkach czynienia dobrze to On sam jest obecny i działa przez człowieka, a za te dobre dzieła czynione na ziemi wierni zasiądą odziani w szaty godowe do uczty wieczystej z Chrystusem, tak jak On teraz z nimi zasiada między ubogimi. Dobroczynność bogatych sprawia, że wielu z nich się nawraca i zaczyna w nich działać łaska Chrystusa, ponieważ wszystko co chrześcijanie czynią, czynią z Chrystusem i w Chrystusie. Paulin zaleca więc, aby ze wszystkich swych sił starać się naśladować Chrystusa, by w ten sposób stawać się „,włosami i złotem Bożym". To Chrystus jest dla swoich wyznawców głową dzięki łasce Bożej i dzięki temu ciągłemu umacnianiu Jego mocą stają się oni zdolni nie tylko służyć innym i stawać się zarówno pasterzami, jak i żywicielami wiernych, ale także wchodzą coraz głębiej w tajemnice i pełne miłości zjednoczenie z Trójcą Świętą ${ }^{40}$. Przywołując przykład cudownego uwolnienia św. Piotra $z$ więzienia i wyprowadzenia go na wolność przez Anioła oraz cuda mające miejsce przy relikwiach św. Feliksa, Paulin poucza, że w życiu wszystkich świętych zawsze obecny jest Chrystus, ale także w każdym

${ }^{38}$ Por. tamże 19, 3, 46, ed. Santaniello, t. 1, s. 552-554: „Quomodo autem infirmata sit, docet ille qui dicit: «crucufixus est enim ex infirmitate»; et quomodo confirmata et posita sit, in eodem habes, quoniam, inquit, «vivit ex virtute Dei»»".

${ }^{39}$ Por. tamże 13, 12, 4, ed. Santaniello, t. 1, s. 414: „Ipsius enim domini exemplum in opera eius gerens praecepisti turbam residere in terra; sic enim Iesus iussit, ut legimus, in terra recumbere".

${ }^{40}$ Por. tamże 23, 27, 1 -10, ed. Santaniello, t. 1, s. 672. 
ochrzczonym poprzez działanie Ducha Świętego, ponieważ działa w nim ta sama łaska, co w świętych ${ }^{41}$.

Przywołując przykład Samsona zachęca, aby nie lękać się ślepoty cielesnej, by w ten sposób nie dać się zwieść bogactwu materialnemu i nie stać niewolnikiem tego świata. W ten sposób Paulin poucza, że ciało poddaje się duszy dla swego dobra. Ludzki ogląd świata może oddalać od Boga, a prawdziwie wierzący pragnie widzieć wszystko oczyma Stwórcy, co jest łaską niebiańską. Człowiek zjednoczony duchowo z Bogiem dzięki Jego łasce nie ma potrzeby patrzenia na ten świat oczyma ciała ${ }^{42}$.

Paulin zaleca jednak ciągłą czujność, gdyż łaska raz otrzymana od Boga może być bardzo łatwo zniszczona. Porównuje to niebezpieczeństwo do brzytwy (używanej przez fryzjera), którą określa szatana. Żyjąc w jedności z Chrystusem, jak to już wcześniej wskazano, chrześcijanie zostali porównani do Jego włosów (crinis). Szatan, zazdrosny o tę jedność, pod przeróżnymi pozorami pragnie ich dotknąć, by je upiększyć, jak u fryzjera, i brzytwą swej złośliwości odciąć, czyli odłączyć człowieka i jego wiarę od Głowy, jaką jest Chrystus. Może w ten sposób pozbawić chrześcijan łaski duchowej ${ }^{43}$.

Paulin przestrzega przed zbytnim zaufaniem wobec drugiego człowieka, nawet zakochanego w swej ulubienicy, czego przykładem jest wspominany już Samson. Chociaż był on obdarowany wielką łaską przez Boga, to ufając podstępnej kobiecie utracił wszystko. Będąc silnym duchowo i fizycznie, dał się jednak zwyciężyć, ulegając cielesnej pożądliwości ${ }^{44}$. Paulin wzywa do bezustannej czujności, gdyż szatan jest gotów pozbawić człowieka wielkiego daru Stwórcy, kusząc do popełnienia grzechu, zwłaszcza przez pychę, głupotę i uśpienie wrażliwości wobec innych. Poucza, że chrześcijanin, który przez nieuwage pozwoli oderwać się od jedności z Bogiem, gdy popełni błąd i zaufa człowiekowi nieuczciwemu, jak Samson, zostaje pozbawiony i mocy, i łaski. Może wpaść w niewolę cielesnych pożądań, stać się ich niewolnikiem, jak zwykłe zwierzę, dać się odrzucić i oderwać od Boga ${ }^{45}$. Gdy jednak ludzie są zjednoczeni z Chrystusem, wówczas wiele rzeczy materialnych i nawet to, co było pewnego rodzaju chlubą naszego życia, np. talent poetycki, czy inne,

${ }^{41}$ Por. tenże, Carmen 15, 245-260, ed. Ruggiero, t. 1, s. 254, spec. wiersz 257: „Nonne unus in omni Christus adest sancto? Sicut viget omnibus idem spiritus in Christo genitis, sic ipsa piorum gratia concordat".

${ }^{42}$ Por. tenże, Epistula 23, 21, 14-18, ed. Santaniello, t. 1, s. 660: „Nam forsitan ille receptis propter futurum mysterium in coma viribus recipere simul, ut amiserat, oculos ideo non desideravit, quia virtus illa caelestis gratiae internis sana luminibus corporeo non egebat obtutu".

${ }^{43}$ Por. tamże 23, 11, 1-9, ed. Santaniello, t. 1, s. 634; R. Lavatori, Satana, un caso serio, Bologna 1996; Nola, Il diavolo.

${ }^{44}$ Por. Paulinus Nolanus, Epistula 23, 11, 13-15, ed. Santaniello, t. 1, s. 636: „Sed carnali victus inlecebra qui gratia spiritali vicerat, cum praevaluisset forti, ab infirmitate superatus est".

${ }^{45}$ Por. tamże 23, 12,15-25, ed. Santaniello, t. 1, s. 638; Jan Paweł II, Aniolowie upadli, czyli szatani (audiencja środowa 13 sierpnia 1986), w: Wierzę w Boga Ojca Stworzyciela, Città del Vaticano 1987, 357-362. 
teraz staje się zbędne. Uwolniony od ziemskich trosk człowiek staje się prawdziwie wolny w Chrystusie i może śpiewać pieśn wolności oraz radować się w pełni. Ta prawdziwa wewnętrzna radość odmalowuje się na ludzkim obliczu i ukazuje drogę innym ${ }^{46}$.

Wielu zaprzyjaźnionych, a nawet zupełnie nieznanych ludzi, dzieliło się z Paulinem swymi troskami i prosiło go o pomoc oraz o konkretne wskazania, jak mają żyć. Paulin dodaje odwagi tym, którzy obawiają się przeciwności, jakie niesie ze sobą codzienne życie oraz śmierć ${ }^{47}$. Przywołując nauczanie św. Pawła przypomina, że jest to łaska nadzwyczajna, bo śmierć niszczy to wszystko, co jest wrogie człowiekowi w świecie doczesnym i oddziela go od spraw boskich. Śmierć jest także nazwana łaską jednoczenia tego, co ludzkie i kruche, z tym, co Boskie. Jako nadzwyczajna łaska „stwarza jedność”. Rzadko spotykane jest u Ojców Kościoła takie eksponowanie nauki, że śmierć anuluje całą trudną doczesność, wszelkie przebyte przeszkody oraz upadki. Przez swoją śmierć Chrystus - prawdziwy Bóg i człowiek - połączył w jedno obie natury (boską i ludzką) i w ten sposób zrealizował wieczne przymierze Boga z człowiekiem ${ }^{48}$.

\section{THE INDISPENSABLE ROLE OF GOD'S GRACE IN UPHOLDING THE VIRTUE OF HOPE IN DAILY LIFE - THE CASE OF PAULINUS OF NOLA}

\section{(Summary)}

Letters and songs of Paulinus of Nola $(\dagger 431)$ require a reader to be keen, careful and critical to the content its carries, specifically from the dogmatic point of view. Paulinus differentiates God's the Father Grace, Christ' Grace, Grace given by the Holy Spirit and finally grace received by people through the intercessions of saints. He never questions the dogma of the Trinity, but he is nonetheless criticised by Hieronymus as being too general in his writings, especially in poems. It is important to note that grace (gratia) as perceived by Paulinus of Nola does not only mean sacramental grace, but also the gift that allows one to uphold the virtue of hope and to grow spiritually and intellectually. In addition, the friendship and help given to a friend is a gift from God and manifestation of His grace.

\footnotetext{
${ }^{46}$ Paulinus Nolanus, Epistula 23, 23, 18-28, ed. Santaniello, t. 1, s. 664: „ut gratiae spiritalis beneficium etiam corporalis forma testetur et libertates internae laetitiam serenitatis revelatae frontis ostentet".

${ }^{47}$ Por. A. Ruggiero, San Paolino maestro di fede e di vita, Napoli - Roma 1994.

${ }^{48}$ Paulinus Nolanus, Epistula 23, 14, 21-27, ed. Santaniello, t. 1, s. 642: „Itaque mortem ipsam moriendo destruxit, solvens, ut scriptum est $(\mathrm{Ef} 2,14)$, «inimicitias in carne sua faciens utrumque unum» id est hominem et Deum, quem in se ipso connexuit Deus homo Christus Iesus, in quo utriusque substantia naturae discordiam posuit et unificantis gratiae aeternum foedus agnovit".
} 
Key words: Paulinus of Nola, hope, grace, friendship, death.

Słowa kluczowe: Paulin z Noli, nadzieja, łaska, przyjaźń, śmierć.

\section{BIBLIOGRAFIA}

\section{Źródła}

Ambrosius, Epistulae, ed. G. Banterle, SAEMO 19-21, Milano - Roma 1988, thum. P. Nowak: Św. Ambroży z Mediolanu, Listy, t. 1, BOK 9, Kraków 1997; t. 2, BOK 22, Kraków 2003; t. 3, BOK 28, Kraków 2012.

Paulinus Nolanus, Carmina, introd., ed. A. Ruggiero: Paulino di Nola, I Carmi, t. 1-2, Napoli - Roma 1996.

Paulinus Nolanus, Epistulae, ed. G. Santaniello: Paolino di Nola, Le Lettere, t. 1-2, Napoli - Roma 1992.

\section{Opracowania}

Conybeare C., Paulinus noster: self and symbols in the letters of Paulinus of Nola, Oxford 2000.

EISWIRTH R., Hieronimus'Stellung zur Literatur und Kunst, Wiesbaden 1955.

LaVATori R., Satana, un caso serio, Bologna 1996.

Mia sola arte è la fede: Paolino di Nola teologo sapienziale, ed. L. Longobardo - D. Sorrentino, Napoli 2000.

Mratschek S., Der Briefwechsel des Paulinus von Nola: Kommunikation und soziale Kontakte zwischen christlichen Intellektuellen, Göttingen 2002.

Nola A., Il diavolo. Le forme, la storia, le vicende di Satana e la sua universale e maleficia prezenza presso tutti i popoli, dall'antichità ai nostri giorni, Roma 1987.

PAŁucki J., Eklezjotwórcza funkcja przyjaźni w nauczaniu Paulina z Noli, SWł 14 (2012) 88-104.

Palucki J., Paulin z Noli. Zapomniany przez wieki, wzorem teologa na dzisiejsze czasy, w: Sprawiedliwość, pokój i radość w postugiwaniu biskupim, w: Ksiega pamiatkowa ku czci Jego Ekscelencji Księdza Biskupa dr. Wiesława Alojzego Meringa z okazji 65. rocznicy urodzin, red. A. Niemira - K. Rulka - J. Szymański, Włocławek 2010, 419-428.

Pietras H., Poczatki teologii Kościoła, Kraków 2000.

Prete S., Motivi ascetici e letterari in Paolino di Nola, Napoli - Roma 1987.

Rinaldis S. DE, Paolineide. Testo latino, traduzione italiana, note e indici, a cura di A. Ruggiero, Strenae Nolanae. Collana di studi diretta da A.V. Nazzaro 9, Marigliano 2002.

Ruggiero A., San Paolino maestro di fede e di vita, Napoli - Roma 1994.

Santaniello G., San Paolino di Nola una vita per Cristo, Napoli 1994.

Santaniello G., Vita di Paolino da Bordeaux vescovo di Nola, Nola - Marigliano 2015.

Skeb M., Christo vivere: Studien zum literarischen Christusbild des Paulinus von Nola, Bonn 1997.

Trout D.E., Paulinus of Nola: life, letters and poems, Berkeley 1999. 